\title{
НЕКОТОРЫЕ АСПЕКТЫ ЭМИГРАЦИИ РУСИНО-УКРАИНСКОГО НАСЕЛЕНИЯ ИЗ АВСТРИЙСКОЙ ГАЛИЦИИ: АГРАРНЫЙ ВОПРОС И РЕГУЛЯТИВНЫЙ ОТВЕТ ${ }^{1}$
}

\section{SOME ASPECTS OF EMIGRATION OF RUSSIAN-UKRAINIAN POPULATION FROM AUSTRIAN GALICIA: AGRARIAN QUESTION AND REGULATORY RESPONSE ${ }^{2}$ \\ A. Topilskiy \\ E. Vorobeva}

Summary: The article deals with the socio-economic problems of emigration from Galicia of rusino-ukrainian peasants in the second half of the XIX - early XX century. It is shown how the Austrian authorities sought to regulate the order of travel abroad. The regulation of migration agencies activities is described.

Keywords: Austria-Hungary, Galicia, peasants, labor migration.

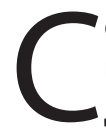
оциально-экономическое развитие Галиции во второй половине XIX века столкнулось с необходимостью разрешения аграрного вопроса. Отмена крепостной зависимости в 1848 году не предусматривала уничтожение помещичьего землевладения и экономических дворянских привилегий, в результате чего крестьяне из-за малоземелья были вынуждены наниматься на работы к землевладельцам. Рост населения, возможность свободной продажи земли вели к сокращению площади среднего крестьянского надела. В Галиции в 1848 году крестьянин имел в среднем 15 моргов земли, в 1859 году - 9,5 моргов, в 1880 - 5,5 моргов, в 1900 - 4,5 морга.

Крестьяне вынуждены были платить за пользование сервитутами, что делало даже середняков зависимыми от помещиков в хозяйственном отношении. Дискриминационность политики в отношении галицийских крестьян со стороны австрийского правительства проявлялась в разных аспектах, одним из которых было то, что украинский крестьянин платил выкуп в 3 раза больше, чем чешский крестьянин, и в 5 раз больше, чем немецкий [3]. Ведущей сферой хозяйствования оставалось сельское хозяйство. Экстенсивная форма его развития,
Топильский Алексей Геннадьевич к.и.н., старший преподаватель, Тамбовский государственный университет имени Г.Р. Державина a-topil@yandex.ru

Воробьева Елизавета Михайловна

Тамбовский государственный университет имени Г.Р. Державина moreno_ool@mail.ru

Аннотация: B статье рассматриваются социально-экономические проблемы эмиграции из Галиции русино-украинских крестьян во второй половине XIXначале XX века. Показано, как австрийские власти стремились упорядочить порядок выезда за границу. Охарактеризована регламентация деятельности миграционных агентств.

Ключевые слова: Австро-Венгрия, Галиция, крестьяне, трудовые миграции.

в то время как европейские страны внедряли капиталистические формы хозяйствования, привела данную сферу до тяжелого состояния, что вело к еще большей эксплуатации крестьян.

Таким образом, реформа не только даровала населению свободу перемещения, но и стала катализатором дальнейшего роста крупных земледельческих хозяйств. Процветали табулярные хозяйства, держателями которых была старая польская шляхта [6, с. 41]. Помещики приобретали земельные наделы обнищавшего, в результате высокой конкуренции на рынке и низкой рентабельности мелких хозяйств, крестьянства. Продажа на аукционе крестьянских хозяйств за задолженности стала довольно частным явлением. Всего за 22 года (1873-1894) были проведены 49823 лицитации, что составило в среднем 2065 лицитаций за год.

Задолженность, которая была непосредственной причиной изъятия земель, превысила за эти годы 12,5 млн гульденов [7, s. 14]. Часто не очень большие задолженности были основанием для проведения лицитаций имущества на куда как большие суммы. В результате оставшиеся без земли и имевшие недостаточные для 
ведения хозяйства наделы люди вынуждены были искать другие способы пропитания.

Высвободившаяся безземельная, маргинальная рабочая сила «бурлила» в аграрных областях Галиции, Буковины и Закарпатья, стремясь найти способ заработать. Позже популярность получила внутренняя и внешняя рабочая миграция, которая долгое время не была особенно интенсивна из-за самобытности крестьянства, сформированной годами закрепощения.

Основными конечными пунктами миграции для русино-украинского населения Австро-Венгрии стали: Российская империя, Германия, США, Канада и страны Латинской Америки [1, с. 248-259]. Миграционная волна была столь крупной, что позже в американских газетах именовалась «славянским нашествием».

Австрийские власти столкнулись с необходимостью упорядочения перемещения населения. Условно регулирование миграционных процессов можно разделить на внутреннее, посредством контроля деятельности коммивояжеров (торговых агентов), и внешнее в виде заключения международных договоров. В данном исследовании фокус внимания направлен на подробный анализ процесса внутренней регламентации.

Миграционная политика Габсбургской империи не была однозначна и во многом зависела от выгоды и курса внешней политики того времени. Миграция в другие страны обнищавшего крестьянства только поддерживалась, поскольку давала государству неплохой доход, одновременно облегчая накалившуюся из-за аграрного перенаселения обстановку в провинциях.

Внутренняя регламентация внешней миграции осуществлялась через контроль деятельности коммивояжеров, которые часто являлись организаторами переселений. С 1852 года согласно положению, в отношении коммивояжеров, каждый торговый путешественник должен был получить правительственное разрешение на ведение посреднической деятельности.

Для подачи заявления на приобретение разрешения необходимо было предоставить подробные сведения не только о своем экономическом благополучии, но и о политических взглядах и моральных воззрениях. Это предположительно могло бы помешать агентам вести подрывную деятельность, противоречащую имперской концепции австро-венгерской государственности [8].

Причем с иностранных коммивояжеров в зависимости от области их деятельности взимался разный налог, наибольший в Чехии, Галиции и Венгрии, где он был равен шесть гульденов, наименьший в Нижней Австрии - четыре гульдена. Налог находился в прямой зависимости от предполагаемого дохода агента. За деятельность в Вене приходилось доплачивать отдельно, и сумма была равна той, что агент платил за целую область - Нижнюю Австрию [8].

Все записи, начиная с бухгалтерских отчетов и заканчивая перепиской с торговой компанией, должны были быть скопированы и храниться у торгового агента. Таким образом, властные органы в любой момент могли проверить учёт на предмет нарушения законодательных норм. Мера кажется несколько однобокой, поскольку в реальности не могла в должной мере контролировать деятельность торговых агентов, но могла помочь легко устранить особенно неугодных властным структурам.

С ростом количества эмигрантов, которые оставляли Галицию, австрийским властям скоро стало понятно, что выезд крестьян из страны скажется на недостатке солдат для армии. Больше того, для эксплуататоров человеческого труда этот выезд означал потерю дешевой рабочей силы. В этих условиях местное население (а именно - рабочая сила) могло требовать и требовало улучшения условий жизни. Были осуществлены действенные мероприятия по прекращение эмиграции. Особенно это касалось молодого поколения призывного возраста. Власти следили за такими людьми, не давали им разрешения на трудоустройство, не давали им паспортов, но, несмотря на это, многим повезло перейти границу с Германией, а потом эмигрировать в Новый свет [2, с. 33, 34]. В результате австро-венгерские власти пытались если не прекратить эмиграцию, то хотя бы ограничить ее. В 1897 г. был принят закон, который позволял осуществлять деятельность агентов только тех фирм, которые имели соглашение с правительством. Значительное влияние на регулирование потоков миграции оказал балканский кризис, во время которого с особой осторожностью относились к отправлению за границу военнообязанных [5, с. 17]. Во всех странах Европы в начале XX века ощущается активная милитаризация государственного аппарата. В то время военное ведомство играло важную роль в правительстве, а решения рейхсрата отошли на второй план [4, с. 239].

Таким образом, политика правительства и внутренняя законодательная регламентация, к которой прибегали для контроля объемов эмиграции, была направлена на сокращение потока покидавших страну жителей путем ограничений, а не на создание выгодных условий жизни внутри страны. 


\section{ЛИТЕРАТУРА}

1. Кабузан В.М. Украинцы в мире: динамика численности и расселения. 20-е годы XVIII века - 1989 год: формирование этнических и политических границ украинского этноса/В.М. Кабузан; Ин-т рос. истории РАН. - М.: Наука, 2006. С.248-259.

2. Маршалл А. Ней. Іван Пилипів - піонер українських поселенців у Канаді // Українська еміграція. І сторія і сучасність. Матеріали міжнародних наукових конференцій, присвячених 100-річчю еміграції українців до Канади / Упоряд. Ю. Ю. Сливка. - Львів: Каменяр, 1992. С. 27-41.

3. Модернізація українського суспільства в середині - у другій половині XIX ст. URL: http://history.vn.ua/compendium//91.html (дата обращения 22.04.2020).

4. Пурахина И.И. Карл Реннер о функциях государства в условиях военного времени // Вестник ТГУ. Серия: гуманитарные науки. 2011. №8. С. $239-243$.

5. Шлепаков А.Н. Українська трудова еміграція в США и Канаді (кінець XIX - початок XX ст.). К.: Вид-во АН УРСР, 1960. 200 с.

6. Ястребов Н.В. Галиция накануне Великой войны 1914 года: С карт. Галиции и Буковины с Угор. Русью. - Петроград: тип. А.Э. Коллинс, 1915. 146 с.

7. Feldman W. Stan ekonomiczny Galicji. Lwów: Uroda, 1900. 32 s.

8. Verordnung des Handelsministeriums, wodurch in Folge Allerhöchster Entschließung vom 25. October 1852 mehrere Bestimmungen zur Regelung des Geschäftsbetriebes der wandernden Handels-Agenten angeordnet werden. URL: http://alex.onb.ac.at/cgi-content/alex?aid=rgb\&datum=18520004\&sei te $=00000993$ (дата обращения 22.04.2020).

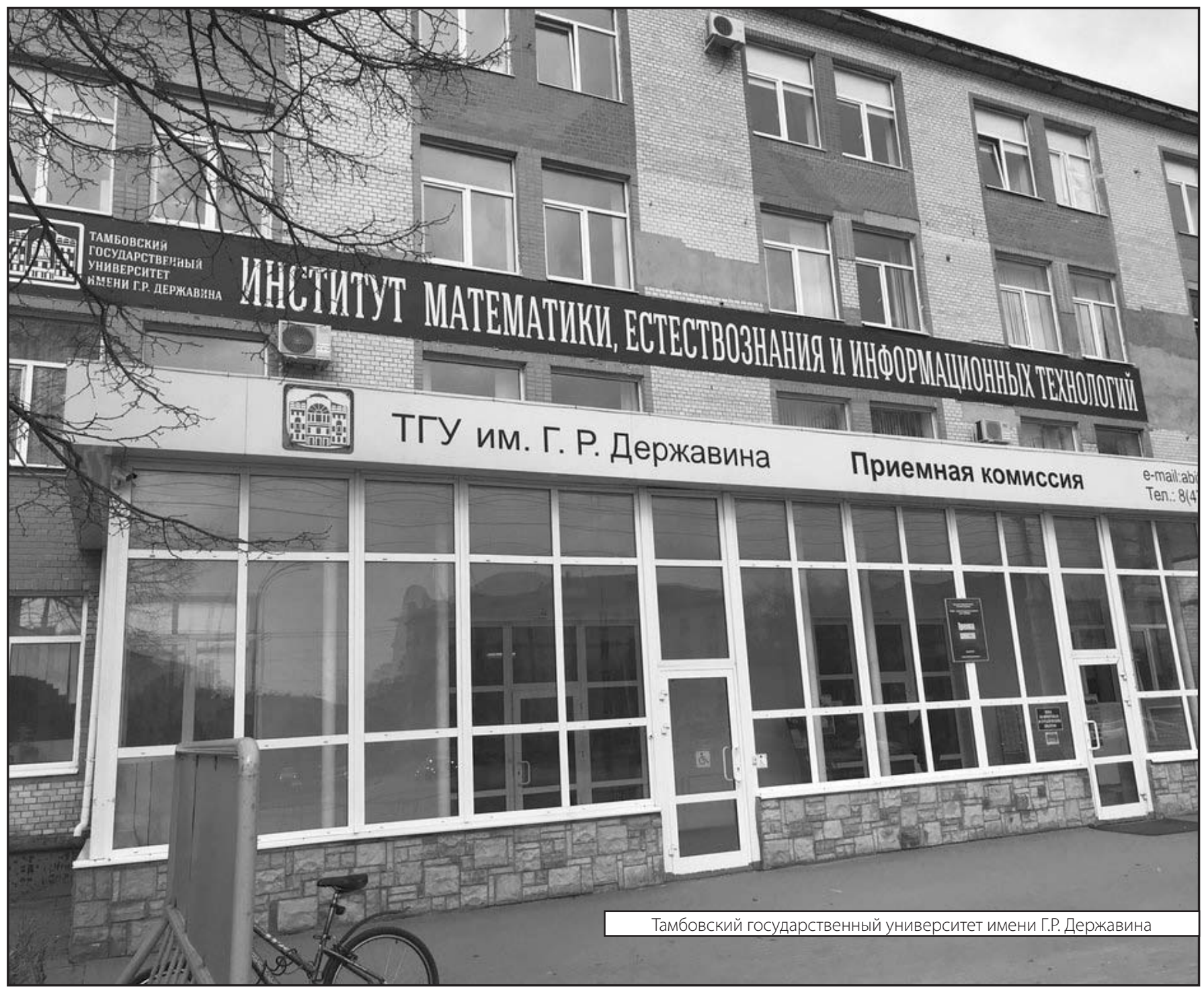

